\title{
Brucella Abortus in Dog Population: An Underestimated Zoonotic Disease
}

\author{
Eduardo Mortola*, Graciela S Miceli and Lautaro Perez Meyer \\ Department of Veterinary Immunology, Argentina \\ *Corresponding author: Eduardo Mortola, Department of Veterinary Immunology, Argentina
}

\begin{tabular}{|c|c|}
\hline ARTICLE INFO & ABSTRACT \\
\hline $\begin{array}{l}\text { Received: 慧 February 08, } 2019 \\
\text { Published: 慧 February 27, } 2019\end{array}$ & $\begin{array}{l}\text { Brucellosis is an infection that affects different animal species and human. This disease } \\
\text { is particularly contagious and cross- species transmission of Brucella spp. can occur. Dogs } \\
\text { infection is usually caused for B. canis. However, B. abortus infection, associated with infect- }\end{array}$ \\
\hline $\begin{array}{l}\text { Citation: Eduardo M, Graciela S M, } \\
\text { Lautaro Perez M. Brucella Abortus in } \\
\text { Dog Population: An Underestimated } \\
\text { Zoonotic Disease. Biomed J Sci \& Tech } \\
\text { Res 15(2)-2019. BJSTR. MS.ID.002681. } \\
\text { Keywords: B. Abortus; Dogs; Zoonosis; } \\
\text { Argentina }\end{array}$ & $\begin{array}{l}\text { ed cattle, has been reported experimentally and under field conditions and transmission } \\
\text { from dog to human is possible. This communication highlights the occurrence of } B \text {. abortus } \\
\text { infection in dogs, revealing for the first time, the analysis of a farm dog population in Argen- } \\
\text { tina that being infected with B. abortus and emphasize the importance of the zoonotic trans- } \\
\text { mission of the diseases in a rural area. In the study reported here, } 195 \text { dog sera were ana- } \\
\text { lyzed, and } 61 \text { of them }(31 \%) \text { were found positive for B. abortus by Buffered Brucella antigen } \\
\text { test; } 54 \text { dogs }(27,7 \%) \text { were then confirmed seropositive for Slow Agglutination test and } \\
\text { 2-mercaptoethanol test, with antibody titer } \geq 1: 100 \text {. Examination of case histories showed } \\
\text { that all the } B \text {. abortus seropositive dogs lived in a proximity with brucellosis seropositive } \\
\text { livestock and may have access to aborted fetuses and placentae from infected cattle, or they } \\
\text { were house dogs that had close contact with farm dogs. Elimination of infected cattle only } \\
\text { may not necessarily eradicate the brucellosis but avoided the contact of dogs from infected } \\
\text { cows should prevent the transmission. }\end{array}$ \\
\hline
\end{tabular}

\section{Introduction}

Brucellosis is an infection that affects different animal species and human. Bacteria of the genus Brucella includes 12 recognized species [1], Brucella abortus, B. melitensis and B. ovis are the typical species found in cattle and small ruminants. B. suis mainly caused porcine brucellosis and other species of interest include $B$. canis and B. ovis, infecting dogs and sheep respectively [2]. This disease is particularly contagious and cross- species transmission of Brucella spp. take place [2]. All biovars of B. abortus and B. melitensis and biovars 1,3 , and 4 of $B$. suis are common zoonotic pathogens $[3,4]$, causing undulant fever and influenza-like symptoms in humans, but B. canis is less recognized as the cause of a zoonosis disease [5]. Brucellosis in dogs has been reported worldwide and is endemic to the Americas; Asia and Africa, serologic surveys of dogs from numerous countries established a wide range of seropositivity, from 1- 28\% [6]. Brucellosis infection in dogs can be caused not only for B. canis, but also dog's infection by B. abortus, B. melitensis, and $B$. suis has been reported experimentally and under natural conditions [7-9]. Clinical signology of Brucellosis infection are not pathognomonic, since dogs may be subclinically affected or may exhibit reproductive disorders in bitches and causes epididymitis, prostatitis, and orchitis in male dogs [10].

$B$ canis can cause both acute and chronic infections in human like other Brucella species [11]. However, epidemiological data concerning B. canis human infection is lacking, because are hardly considered in differential diagnoses and identification of the bacteria infection via serology is tough [12]. Human cases of $B$. canis are rare and mainly resulted from contact aborting bitches or veterinary practitioners [13]. It has been previously reported B. abortus natural infection in dogs associated with infected cattle, and horizontal transmission of the disease is possible from dog to dog, cattle to dog, dog to cattle, and dog to human $[14,15]$. However, brucellosis caused by B. abortus typically manifests in humans as non-specific clinical signs, including malaise, fatigue, arthritis and fever, with the development of a chronic disease [16]. Human to human transmission can occur via placenta or breastfeeding [17]. This infection is most commonly transmitted through direct contact with tissues from infected animals (aborted fetal tissue) or unpasteurized dairy products [16]. 
Usually the clinically infection were reported from people who work in close contact with cows, that include veterinarians and farmers [13]. Although the global prevalence of brucellosis in humans is unknown, mainly due to underdiagnosis and under notification, it is estimated that worldwide affects 500,000 people a year, especially in countries in the Mediterranean area, Arabia, India, Mexico, America Central and South America [18]. In Argentina, official data reported that the estimated prevalence of brucellosis in cattle, caused by B. abortus, is $10-15 \%$ among herds and $4-5 \%$ among individual animals [19]. There is not epidemiological data regarding human infection with B. abortus through dogs. This communication highlight information regarding occurrence of B. abortus infection in dogs, emphasizing B. abortus as an underestimated pathogen in canine. Revealing for the first time, the analysis of a farm dog population in Argentina that being highly infected with $B$. abortus and emphasize the importance of the zoonotic transmission of the diseases in a rural area. From 2015 to 2018, a total of 195 serum samples from dogs that live in a farm environment in a rural area of Buenos Aires province of Argentina were collected and tested for B. abortus and B. canis infections.

Smooth Brucella spp. (B. abortus, B. suis or B. melitensis) express the immunodominant $O$ side chain on the lipopolysaccharide of their surface. Therefore, this side chain forms the antigenic basis of diagnostic tests, such the Buffered Brucella Antigen Test (BBAT), Slow Agglutination Test (SAT) and 2-Mercaptoethanol test (2-ME), can detect smooth species. Tests for rough Brucella species as B. canis differ from test for smooth Brucella spp, since $B$. canis does not hold the $O$ side chain on its surface, the Rapid Slide Agglutination Test (RSAT) is used for serologic analysis. Therefore, B. canis infected dogs are not possible to have positive results for B. abortus test and vice versa [20]. The dog serum samples were analyzed by using the BBAT as a screening test. Then, the positive samples were confirmed by SAT and 2-ME tests. Also, all the dog's serum was serological tested for $B$. canis infection by RSAT. In the study reported here, sera from 61 dogs (31\%) were found positive by BBAT; 54 dogs $(27,7 \%)$ were confirmed seropositive for SAT and 2-ME with antibody titer $\geq 1: 100 ; 7$ (3,5\%) dog's serum samples were demonstrated positive for $B$. canis, and only 1 dog resulted positive for both B. abortus and B. canis.

Examination of case histories showed that all the B. abortus seropositive dogs lived in a proximity with brucellosis seropositive livestock and may have access to aborted fetuses and placentae from infected cattle, or they were house dogs that had close contact with farm dogs. Vaginal discharges from B. abortus positive cattle have been reported to persist more than 40 days after abortion or parturition and turned into an infected source for dogs. Seroconversion in B. abortus infected dogs can occur between 5- and 20-days post-infection and excretion of Brucella spp. into the environment via urine or feces have been reported [21]. This via could explain the infection of the house dogs that never been to the farm, which were apparently infected by ingesting brucella contaminated feces or urine from the farm dogs. By the Argentinian government law, the brucellosis seropositive cattle should be removed under surveillance program in order to avoid the spread of the disease. Since canine brucellosis is not part of the surveillance program, dogs could play the role of reservoir hosts for B. abortus.

So far there is no evidence that dogs play an active epidemiological role in the transmission of B. abortus to humans or cattle. However, this source of transmission should not be underestimated, since cross species transmission of Brucella spp. is possible. Sporadic transmission of B. canis from pet dogs to their owners has been reported [22]. In addition, other report describes $B$. suis detection in dogs and warning the public about the potential pig-to-human transmission [23]. Because B. abortus is more pathogenic to humans than $B$. canis, patients exposed to $B$. abortus farm dogs should be tested for the infection and monitored for clinical signs. B. abortus infected dogs have the potential to infect cattle and could be a threat of brucellosis transmission than had been assumed before. Although the risk of transmission appears to be mild, infection of human or cattle associated with Brucella-infected dogs would cause unfavorable political and economic consequences. Elimination of reactor cattle only may not necessarily eradicate the disease, but removal of contact dogs from infected herds should prevent such transmission. During Brucellosis eradication programs, serological testing of dogs for $B$. abortus may be a valuable indicator (sentinel) of the presence of brucellosis in cattle [21].

Brucellosis is a thoughtful, globally distributed zoonotic disease and ingestion of contaminated dairy products is the major risk for brucellosis in disease-endemic areas [16]. However, should not be underestimated the potential transmission of B. abortus to humans in contact with infected farm dogs. More than $60 \%$ of human pathogens are estimated to have an animal source, and the incidence of a disease is affected by environmental factors, therefore diverse approaches are valid in order to control the incidence of zoonotic diseases [24,25].

\section{References}

1. Whatmore AM, Koylass MS, Muchowski J, Edwards Smallbone J, Gopaul KK, et al. (2016) Extended multilocus sequence analysis to describe the global population structure of the genus Brucella: phylogeography and relationship to biovars. Front Microbiol 7: 2049.

2. Olsen SC, Palmer MV (2014) Advancement of knowledge of Brucella over the past 50 years. Vet Pathol 51(6): 1076-1089.

3. Godfroid J, Coeckart A, Liautard JP, Kohler S, Fretin D, et al. (2005) From the discovery of the Malta fever's agent to the discovery of a marine mammal reservoir, brucellosis has continuously been a re-emerging zoonosis. Vet Res 36(3): 313-326.

4. Maudlin I, Eisler MC, Welburn SC (2009) Neglected and endemic zoonoses. Philos Trans R Soc Lond B Biol Sci 364(1530): 2777-2787.

5. Krueger WS, Lucero NE, Brower A, Heil GL, Gray GC (2014) Evidence for unapparent Brucella canis infections among adults with occupational exposure to dogs. Zoonoses Public Health 61(7): 509-518. 
6. McDermott J, Grace D, Zinsstag J (2013) Economics of brucellosis impact and control in low-income countries. Rev Sci Tech 32(1): 249-261.

7. Barr SC, Elite BE, Roy AF, Miller R (1986) Brucella suis biotype 1 infection in a dog. J Am Vet Med Assoc 189(6): 689-687.

8. Hollett RB (2006) Canine brucellosis: outbreaks and compliance. Theriogenology 66(3): 575-587.

9. Aras Z, Ateş M, Uçan US (2009) Brucella suşlarının izolasyonu ve biyotiplendirilmesi. Eurasian J Vet Sci 25: 51-59.

10. Pidgeon GL, Scanlan CM, Miller WR, Mayer TW (1987) Experimental infection of dogs with Brucella abortus. Cornell Vet 77: 339-347.

11. Moore JA (1969) Brucella canis infection in dogs. J Am Vet Med Assoc. 155(12): 2034-2037.

12. Canine (2007) Brucellosis: Brucella canis p. 10.

13. Polt SS, Dismukes WE, Flint A, Schaefer J (1982) Human brucellosis caused by Brucella canis: Clinical features and immune response. Ann Intern Med 97(5): 717-719.

14. Krueger WS (2011) A seroepidemiological study of canine zoonoses among persons occupationally exposed to dogs. University of Iowa pp. 113-121.

15. Forbes LB (1990) Brucella abortus infection in 14 farm dogs. J Am Vet Med Assoc 196(6): 911-916.

16. Tessaro SV, Forbes LB (2004) Experimental Brucella abortus infection in wolves. J Wildl Dis 40(1): 60-65.

\section{ISSN: 2574-1241}

DOI: 10.26717/BJSTR.2019.15.002681

Eduardo Mortola. Biomed J Sci \& Tech Res

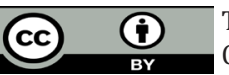

This work is licensed under Creative Commons Attribution 4.0 License

Submission Link: https://biomedres.us/submit-manuscript.php
17. Kose S, Serin Senger S, Akkoclu G, Kuzucu L, Ulu Y, et al. (2014) Clinical manifestations, complications, and treatment of brucellosis: evaluation of 72 cases. Turk J Med Sci 44(2): 220-223.

18. Tuon FF, Gondolfo RB, Cerchiari N (2017) Human-to-human transmission of Brucella - asystematic review. Trop Med Int Health 22(5): 539-546.

19. Enfermedades infecciosas: brucelosis (2013) Guía para el equipo de Salud, Ministerio de Salud Pcia. de la Nación, Argentina.

20. Lucero NE, Ayala SM, Escobar GI, Jacob NR (2006) Brucella isolated in humans and animals in latin america from 1968 to 2006. Epidemiol Infect 136(4): 496-503.

21. Mateu De Antonio EM, Martin M, Casal J (1994) Comparison of serologic tests used in canine brucellosis diagnosis. J Vet Diagn Invest 6(2): 257 259.

22. Moreno E (2014) Retrospective and prospective perspectives on zoonotic brucellosis. Front Microbiol 5: 213.

23. Hensel ME, Negron M, Arenas Gamboa AM (2018) Brucellosis in Dogs and Public Health Risk. Emerg Infect Dis 24(8): 1401-1406.

24. Ramamoorthy S, Woldemeskel M, Ligett A, Snider R, Cobb R, et al. (2011) Brucella suis Infection in Dogs, Georgia, USA. Emerg Infect Dis 17(12): 2386-2387

25. Cutler SJ, Fooks AR, van der Poel WHM (2010) Public health threat of new, reemerging and neglected zoonoses in the industrialized world. Emerg Infect Dis 16(1): 1-7.

$\begin{array}{ll}\text { BIOMEDICAL } & \text { Assets of Publishing with us } \\ \text { RESEARCHES } & \text { - Global archiving of articles } \\ & \text { - Immediate, unrestricted online access } \\ \end{array}$

